\title{
PRAKTIK PENGUNGKAPAN SOSIAL: STUDI KOMPARATIF DI ASIA TENGGARA
}

\author{
Edy Supriyono \\ STIE BANK BPD JATENG \\ Djoko Suhardjanto \\ Universitas Sebelas Maret Surakarta \\ e-mail: suhardjanto04@yahoo.com
}

\begin{abstract}
This research aims to examine the effect of corporate governance on the corporate social disclosure in the South East Asia companies as well as to test the difference of the level of corporate social disclosure (CSD) between three countries: Indonesia, Malaysia, and Thayland. Variables in the research are: the number of commissioners, board competence, the proportion of independent commissioners, audit committee size, the proportion of independent audit committees, and ownership of managerial. Global Reporting Initiative 2006 is used to measurement CSD. Sample in this study were drawn from the company's annual report on Indonesia Stock Exchange, Kuala Lumpur Stock Exchange, and Thayland Stock Exchange in 2009. There are a significant predictors namely the competency of the board of director, numbers of audit committee and proportion independent audit committees on corporate social disclosure. The number of commissioners, the proportion of independent commissioners, and ownership of managerial are not as determinant significant that only firms size and industry type. There are different corporate social disclosure practice in Indonesia, Malaysia and Thayland. Level of disclosure in Indonesia over an average of 40,14\%, 58,52\% in Malaysia, and 54,12\% in Thayland. This is caused by differences in corporate governance practices in those countries.
\end{abstract}

Keywords: corporate social disclosure, corporate governance, comparative study.

\begin{abstract}
Abstraksi
Penelitian ini bertujuan untuk menguji pengaruh corporate governance terhadap pengungkapan sosial perusahaan pada perusahaan-perusahaan di Asia Tenggara serta untuk menguji perbedaan tingkat pengungkapan sosial perusahaan (CSD) antara tiga negara: Indonesia, Malaysia, dan Thailand. Variabel dalam penelitian ini adalah: jumlah komisaris, dewan kompetensi, proporsi komisaris independen, ukuran komite audit, proporsi komite audit independen, dan kepemilikan manajerial. Global Reporting Initiative 2006 digunakan untuk pengukuran CSD. Sampel dalam penelitian ini diambil dari laporan tahunan perusahaan di Bursa Efek Indonesia, Kuala Lumpur Stock Exchange dan Bursa Efek Thailand pada tahun 2009. Hasil penelitian menunjukkan adanya prediktor yang signifikan yaitu kompetensi dewan direktur, jumlah komite audit dan proporsi komite audit independen terhadap pengungkapan sosial perusahaan. Jumlah komisaris, proporsi komisaris independen, dan kepemilikan manajerial tidak sebagai penentu signifikan yang ukuran hanya perusahaan dan industri jenis. Ada perbedaan pengungkapan sosial perusahaan dalam praktik di Indonesia, Malaysia dan Thailand. Tingkat pengungkapan di Indonesia lebih dari rata-rata sebesar 40,14\%; 58,52\% di Malaysia dan 54,12\% di Thailand. Hal ini disebabkan oleh perbedaan dalam praktik tata kelola perusahaan di negara-negara tersebut.
\end{abstract}

Kata kunci: pengungkapan sosial perusahaan, tata kelola perusahaan, komparatif

\section{PENDAHULUAN}

Penelitian ini bertujuan untuk membandingkan tingkat pengungkapan sosial (corporate social disclosure atau CSD) perusahaan di Asia Tenggara dan menguji pengaruh corporate governance $(C G)$ terhadap praktik pengungkapan sosial perusahaan di Asia Tenggara. 
Corporate governance dalam penelitian ini diprensentasikan dengan 1) ukuran dewan komisaris, 2) kompetensi komisaris utama, 3) proporsi komisaris independen, 4) ukuran komite audit, 5) proporsi komite audit independen, 6) kepemilikan manajemen.

Keberhasilan yang berkelanjutan bagi sebuah perusahaan adalah hal yang tidak bisa diabaikan. Oleh karenanya setiap perusahaan harus selalu berusaha meningkatkan performance-nya. Performance perusahaan menurut Elkington (1994) diukur dalam tiga dimensi yaitu: profit, planet dan people. Konsep ini terkenal dengan istilah konsep Triple Bottom Lines (TBL). Didalam konsep TBL, profit berarti perusahaan harus memperoleh laba, planet berarti perusahaan harus memperhatikan masalah lingkungan dan people berarti perusahaan harus memperhatikan aspek sosial Elkington (1994). Aspek sosial yang sebelumnya kurang mendapat perhatian (Fauzi, Stevenson dan Rahman 2010), dalam TBL menjadi bagian strategis dalam rangka keberhasilan perusahaan. Oleh karenanya penelitian ini hanya fokus pada aspek sosial perusahaan utamanya pengungkapan sosial.

Perusahaan yang telah memperhatikan aspek sosial serta mengungkapkannya diharapkan dapat mengurangi problem sosial. Namun kenyataan beberapa fenomena problem sosial melibatkan perusahaan. Hal tersebut dapat dilihat dari beberapa pernyataan maupun kejadian berikut: Djamin, Anggota Komisi Antar Pemerintah ASEAN untuk Hak Asasi Manusia (HAM) menyampaikan prioritas organisasinya di Asia Tenggara adalah tanggungjawab korporasi terhadap HAM karena masalah ini masih merupakan masalah yang besar (Republika.com, 2010a). Kompas.com (2010a) melansir bahwa Komnas HAM Indonesia, melaporkan adanya pelanggaran HAM oleh perusahaan perkebunan minyak sawit milik Malaysia. Pelanggaran ini mencakup aspek sosial di antaranya perampasan hak tanah, tidak terpenuhinya hak buruh, dan kriminalisasi pekerja. Di Indonesia, jumlah kasus pelanggaran HAM setiap tahun mengalami peningkatan (Media Indonesia.com 2010a). Sejak Januari 2008 hingga November 2010, Komisi Nasional Hak Asasi Manusia (Komnas HAM) setiap tahun menangani rerata lima ribu kasus. "Kasus-kasus itu masih didominasi oleh masalah antara penduduk lokal dengan perusahaan besar di daerah" (Media Indonesia.com 2010b).

Demonstrasi Hari Buruh 1 Mei 2011 di Malaysia diikuti 70 Non Govermance Organization $(N G O)$, mahasiswa dan pelajar, mereka menentang kapitalisme, perdagangan bebas, menuntut keselamatan kerja dan gaji minimum yang cukup (MalaysiaKini.com 2011b). Berikut pernyataan peserta demonstrasi seminggu sebelumnya "Tumpuan terhadap arah pertumbuhan ekonomi semata-mata hanya akan merangsang persaingan di kalangan kaum pemodal tanpa kawalan seterusnya menggalakkan penindasan ke atas pekerja," (MalaysiaKini.com 2011c). Di Indonesia demonstrasi memperingati Hari Buruh se-dunia 2011 dikiuti 67 elemen buruh, ribuan massa buruh dan mahasiswa di Bundaran Hotel Indonesia (HI). Para buruh menuntut pemerintah dan Dewan Perwakilan Rakyat Republik Indonesia (DPR RI) segera menetapkan Undang-Undang (UU) tentang Badan Penyelenggara Jaminan Sosial (Republika,com 2010b). Begitu pula yang terjadi demo-demo buruh di tahun 2012 masih berlangsung bahkan semakin meningkat. Aksi sweeping buruh di Indonesia telah membuat 292 perusahaan berhenti beroperasi, akibat aksi itu, sebanyak 6 perusahaan asing telah menutup operasi pabrik mereka di Indonesia (viva.co.id, 7 November 2012).

Masalah buruh lainnya adalah masalah pekerja anak. Survei pekerja anak tahun 2009 yang dilakukan oleh Badan Pusat Statistik (BPS) mencatat ada sekitar 1,7 anak di Indonesia menjadi pekerja (Kompas.com 2010 c). Menurut Koordinator International Labour Organization (ILO) wilayah Indonesia bidang penanganan pekerja anak Abdul Halim, jumlah pekerja anak di Indonesia tinggi, yaitu 2,6 juta jiwa (TempoInteraktif.com 2011b). Angka tersebut, menunjukkan bahwa perusahaan belum mengikuti aturan baik nasional maupun internasional tentang pekerja anak dibawah umur, yang merupakan aturan untuk menjaga kondisi sosial masyarakat yang baik.

Sedangkan problem sosial di Thayland antara lain penyelewengan yang dilakukan perusahaan dibawah kelompok bisnis Thaksin, merupakan penyebab runtuhnya pemerintahan Thaksin sebagai Perdana Menteri tahun 2006 (TempoInteraktif.com 2006).

Fakta problem sosial tersebut, mengindikasikan kurangnya perhatian perusahaan di 
Asia Tenggara terhadap masalah sosial. Problem sosial baik yang berkaitan dengan Hak Asasi Manusia (HAM), pekerja anak maupun buruh menunjukkan bahwa hal ini merupakan masalah yang besar dan perlu adanya solusi. Mengacu pendapat Anderson dan Franke (1980), dimana pengungkapan sosial merupakan elemen informasi penting yang dibutuhkan oleh mereka yang terlibat di pasar modal karena pengungkapan sosial memiliki kandungan informasi serta memiliki nilai positif di pasar modal, maka aspek sosial memiliki pengaruh yang besar terhadap keberlangsungan operasional perusahaan sehingga pengungkapan sosial perusahaan di Asia Tenggara penting untuk diteliti.

Penelitian di Asia Tenggara tentang tingkat pengungkapan sosial misalnya dilakt kan Nurkhin (2009) dan Suhardjanto - Afni (2009) dengan menggunakan teori agensi, serta standar pengungkapan yang dibuat oleh GRI 2006. Keduanya mengindentifikasikan bahwa luas pengungkapan sosial di Indonesia menunjukkan angka 21\% dan 22,3\% pada tahun 2007. Penelitian Haniffa dan Cooke (2005) di Malaysia menemukan luas pengungkapan $25,76 \%$ pada tahun 1996 dan 38,29\% pada tahun 2002. Jika dilihat dari persentase jumlah perusahaan yang melakukan pengungkapkan sosial di Indonesia sekitar 92\% (Murwaningsari 2008) dan 90\% (Suhardjanto dan Afni 2009), sedang di Malaysia tahun 1996 sampai dengan 2002, 100\% (Haniffa dan Cooke 2005). Penelitian Kuasirikun dan Sherer (2004) di Thayland menghasilkan kesimpulan bahwa berbagai aspek pengungkapan sosial di Thailand gagal berfungsi sebagai media perusahaan untuk berkomunikasi dengan stakeholder, artinya pengungkapan sosial belum menjadi sarana komunikasi yang efektif guna menjembatani perusahaan terhadap stakeholder. Temuan diatas menunjukkan bahwa tingkat pengungkapan sosial oleh perusahaan di Asia Tenggara rendah sedangkan presentase jumlah perusahaan yang melakukan pengungkapan sosial dibanding yang tidak melakukan pengungkapan sosial tinggi, bahkan di Thayland pengungkapan sosial gagal menjalankan fungsinya sebagai komunikasi perusahaan terhadap stakeholder. Kondisi dimana presentase jumlah perusahaan yang mempraktikkan pengungkapan sosial yang cukup tinggi sementara tingkat keluasan pengungkapan sosial yang rendah, serta gagalnya CSD sebagai alat komunikasi dengan stakeholder, mengindikasikan bahwa perusahaan di Asia Tenggara belum memiliki kepedulian sosial yang cukup baik. Hal ini karena, perusahaan pada umumnya baru melakukan pengungkapan sosial tetapi belum memperhatikan kwalitas pengungkapan sosial.

Penelitian yang menguji pengaruh Corporate Governance (CG) terhadap pengungkapan sosial (Corporate Social Disclosure atau $C S D$ ) sekaligus membandingkan praktik di beberapa negara misalnya dilakukan Aquilera, Williams, Conley dan Rupp (2006). Mereka melakukan penelitian dengan membandingkan pengaruh $C G$ terhadap praktik $C S D$ di United Kingdom (UK) dan United State (US). Mereka menemukan bahwa terdapat perbedaan praktik pengungkapan sosial di Inggris dan Amerika yang disebabkan oleh perbedaan $C G$ di kedua negara. Penelitian ini juga menemukan bahwa perbedaan tingkat perhatian investor institusional terhadap praktik pengungkapan sosial; $U K$ memiliki perhatian lebih besar terhadap masalah sosial dibanding di $U S$, Aquilera at. al., (2006).

Penelitian ini mengambil sampel pada perusahaan yang tercatat di bursa efek tiga negara yaitu Indonesia, Malaysia dan Thailand untuk mewakili perusahaan yang tercatat pada bursa di Asia Tenggara. Hal ini dikarenakan diketiga negara tersebut memiliki perbedaan dalam praktik penerapan $C G$. Indonesia menganut sistem two-board system (Lukviarman, 2001; Sabeni, 2002), Malaysia menganut sistem single-board system (Haniffa dan Cooke, 2005) sedangkan Thailand tidak jelas menganut sistem yang mana dari kedua sistem tersebut (Kuasirikun dan Sherer, 2004).

Belum adanya penelitian yang membandingkan praktik pengungkapan sosial $(C S D)$ di Asia Tenggara, serta banyaknya fenomena sosial yang melibatkan perusahaan di Asia Tenggara menjadikan penelitian ini penting untuk dilakukan. Berdasarkan uraian tersebut, maka judul penelitian ini adalah: "Praktik Pengungkapan Sosial: Studi Komparatif di Asia Tenggara".

Hasil penelitian ini diharapkan dapat memberikan kontribusi bagi akademisi, praktisi, stakeholder dan regulator di Asia Tenggara. Bagi akademisi, menjadi referensi bagi penelitian mengenai praktik pengungkapan 
sosial pada perusahaan di Asia Tenggara, khususnya yang terdaftar di Bursa Efek Indonesia (BEI), Kuala Lumpur Stock Exchange (KLSE) dan Thailand Stock Exchange (TSE). Bagi praktisi, bermanfaat untuk memberikan pengetahuan tentang praktik pelaksanaan corporate governance dan pengungkapan sosial pada perusahaan yang dapat digunakan sebagai bahan pertimbangan manajemen dalam praktik penerapan pengungkapan sosial. Bagi stakeholder dan pihak-pihak yang berkepentingan, dapat dijadikan pertimbangan dalam pengambilan keputusan dan melaksanakan fungsi pengawasan terhadap pengelolaan perusahaan, terutama dalam pengungkapan sosial perusahaan. Bagi regulator, penelitian ini dapat menggunakan penelitian untuk menetapkan regulasi terkait pengungkapan social di Asia Tenggara khususnya di Indonesia, Malaysia dan Thailand.

\section{LANDASAN TEORI DAN PENGEM- BANGAN HIPOTESIS}

Penelitian ini menggunakan CSD sebagai variabel dependen dan corporate governance sebagai variabel independen.

\section{Corporate Social Disclosure (CSD)}

Terdapat berbagai definisi mengenai corporate social disclosure (CSD). Hackston dan Milne (1996) mendifinisikan pengungkapan sosial perusahaan $(C S D)$ sebagai penyediaan informasi keuangan dan non-keuangan yang berkaitan dengan interaksi organisasi dengan masyarakat sosial, sebagaimana dinyatakan dalam laporan tahunan atau laporan sosial terpisah. Definisi lain diungkapkan Gray, Javad, Power, and Sinclair (2001) yang menyatakan bahwa pengungkapan sosial dapat dimaknai serta terdiri dari informasi yang menggambarkan kegiatan korporasi berhubungan dengan, aspirasi dan kegiatan sosial berkaitan dengan karyawan, isu konsumen, persamaan peluang, perdagangan yang adil, tata kelola perusahaan dan sejenisnya. Definisi lain mengenai pengungkapan sosial yaitu proses penyediaan informasi yang dirancang untuk akuntabilitas sosial yang biasanya dilakukan oleh organisasi yang bertanggung jawab dan dengan demikian termasuk informasi dalam laporan tahunan, publikasi khusus atau bahkan iklan berorientasi sosial (Gray, Owen dan
Maunders 1987). Pengungkapan sosial dalam perspektif ini, diasumsikan bahwa entitas dipengaruhi oleh masyarakat dan, pada gilirannya, memiliki pengaruh pada masyarakat di mana perusahaan beroperasi dan dipandang sebagai metode yang diharapkan manajemen dapat digunakan untuk berinteraksi dengan masyarakat yang lebih luas untuk mempengaruhi persepsi eksternal tentang organisasi mereka (Deegan, 2002).

Parker (1986) menyimpulkan bahwa pengungkapan sosial dapat berfungsi sebagai respon dini perusahaan terhadap takanan peraturan dan sebagai counter terhadap intervensi pemerintah atau tekanan dari kelompok eksternal. Pandangan ini menilai bahwa corporate social disclosure dapat digunakan untuk mengantisipasi atau menghindari tekanan sosial sekaligus digunakan untuk meningkatkan reputasi perusahaan.

Berdasarkan penjelasan tersebut maka dapat disimpulkan bahwa $C S D$ adalah penyampaian informasi kegiatan perusahaan yang berkaitan dengan sumber daya manusia, produk dan kegiatan sosial perusahaan lainnya yang dipublikasikan baik dalam laporan keuangan maupun non-keuangan dengan tujuan memperkecil konflik perusahaan dengan stakeholder.

\section{Guidelines Reporting Initiative (GRI)}

Pada saat ini banyak metode yang dapat digunakan dalam pengungkapan sosial antara lain: 1. Social Accountability (SA) 8000 yang diterbitkan oleh Sacial Accountability International (SAI): Global social accountability standart based on UN Universal Declaration of Human Right, konvensi perlindungan anak International Labour Organization (ILO). 2. Account Ability (AA) 1000 Framework yang dibangun oleh Institute of Social and Ethical Accountability (ISEA) yang bertujuan membantu organisasi membangun akuntabilitas dan social responsibility termasuk didalamnya kualitas sosial, ethical accounting, auditing dan reporting. 3. International Standart Organization (ISO) 14001 yang di keluarkan oleh International Organization for Standartdization merupakan pedoman untuk sistem manajemen lingkungan termasuk didalamnya kebutuhan hukum dan informasi yang berkaitan dengan aspek lingkunan (ISO, 2004). 4. Global Reporting Initiative (GRI) 2006, salah satu 
indikator yang banyak diaplikasikan secara luas oleh organisasi.

Berbagai metode diatas kebanyakan memiliki kelemahan antara lain bersifat terlalu fokus atau sebaliknya melebar kecuali GRI (Ballou, Heitger, dan Landes, 2006; Suhardjanto, 2008). SA 8000 SAI fokus pada HAM, AA1000 Framework tidak fokus hanya pada pengungkapan saja, dan ISO1400 lebih fokus pada masah lingkungan. Oleh karena itu, penelitian ini mengunakan GRI 2006 dalam pengungkapan sosial perusahaan. Alasan lain digunakan GRI 2006 karena, 1). Semakin banyak perusahaan di dunia yang menggunakan GRI, data per 15 Desember 2010 jumlahnya mencapai hampir 2537 perusahaan di lebih dari 60 negara (GRI Report List, 2010). 2). GRI mempunyai dukungan yang kuat dari perusahaan seluruh dunia yang merupakan pertemuan multistakeholder sehingga dapat memperoleh ferivikasi secara umum (Ballou. at al 2006). 3). Banyak penelitian yang menggunakan GRI antara lain Suhardjanto, Tower dan Brown (2008), Nurkhin (2009) dan Suhardjanto dan Afni (2009) di Indonesia. 4). GRI dalam laporan sosial memfokuskan pada kinerja ekonomi dan sosial perusahaan untuk meningkatkan kualitas dan manfaat sustainability reporting (Utama, 2003). Selain itu, GRI mampu mendorong perusahaan untuk menyusun target, selanjutnya perusahaan mampu mencapai dan melaporkan atau tidak target yang telah dicapai tersebut. Bila perusahaan tidak mencapai targetnya, maka harus memberikan argumentasi. Cara seperti ini membantu stakeholder mengukur akuntabilitas perusahaan (Ballou, at al 2006).
Adapun item-item pengungkapan sosial menurut GRI 2006 terdiri dari 22 point seperti terlihat dalam tabel 1. Aspek aspek kinerja sosial diatas cukup lengkap dilihat dari berbagai sudut pandang stakeholder baik pelanggan, karyawan, manajemen, pemilik maupun pemerintah dan masyarakat.

\section{Indek Pengungkapan}

Indeks pengungkapan adalah suatu alat berbasis kualitatif yang dirancang untuk mengukur serangkaian item yang apabila dikumpulkan (dijumlahkan), menghasilkan skor pengganti yang mengindikasikan tingkat pengungkapan dalam konteks tertentu untuknya indeks yang direncanakan tersebut (Coy, Tower dan Dixon, 1993).

Ada 4 tipe pengungkapan sosial yaitu pertama indek yang memberikan bobot yang sama kepada setiap item lingkungan pada indeks yang sama dalam menghitung angkaangka indeks. Jika sebuah perusahaan menyingkapkan setiap item didalam daftar, maka akan diberi angka satu (1) dan nol (0) jika sebaliknya. Tidak ada sanksi yang diberikan kepada perusahaan yang menyingkapkan informasi yang tidak relevan. Tujuan dari digunakannya sebuah indeks dikotomi murni adalah untuk mengurangi subyektivitas dalam menentukan bobot. Varian dari jenis yang pertama ini adalah sistem dikotomi dengan bobot diferensial (jenis kedua). Sebuah sistem pembobotan membebani sebuah item sosial yang tergantung kepada seberapa penting item tersebut (Suhardjanto, 2008).

Tabel 1: Daftar Aspek Kinerja Sosial

\section{Global Reporting Initiative 2006}

\begin{tabular}{llll}
\hline 1. & Kesehatan dan Keamanan Pelanggan & 12. & Hak Asasi Manusia \\
2. & Pemasangan Label bagi Produk dan Jasa & 13. & Non-diskriminasi \\
3. & Komunikasi Pemasaran & 14. & Kebebasan Berserikat dan Perjanjian \\
& & & Bersama \\
4. & Keleluasaan Pribadi (privacy) Pelanggan & 15. & Pekerja Anak \\
5. & Kepatuhan Penggunaan produk dan Jasa & 16 & Kerja Paksa dan Kerja Wajib \\
6. & Pekerjaan & 17. & Praktik Pengamanan \\
7. & Tenaga Kerja dan Hubungan Manajemen & 18. & Komunitas \\
8. & Kesehatan dan Keselamatan Jabatan & 19. & Korupsi \\
9. & Pelatihan dan Pendidikan & 20. & Kebijakan Publik \\
10. & Keberagamaan dan Keselamatan Setara & 21. & Kelakuan Tidak Bersaing \\
11. & (Praktik) Investasi dan Pengadaan & 22. & Kepatuhan Hukum dan Peraturan \\
\hline
\end{tabular}
Sumber: GRI 2006 
Jenis indeks penyingkapan yang ketiga adalah jangkauan skor dengan semua item yang memiliki bobot yang sama. Coy at. al. (1993) menggunakan sebuah skala kualitas tiga poin untuk menangkap perbedaan pada setiap item. Mereka menggunakan skor ' 1 ' untuk kriteria yang kurang, skor (2) untuk kriteria memuaskan dan skor '3' untuk kriteria yang bagus. Sistem yang menggunakan skor dengan rentang yang lebih banyak mungkin lebih valid, tetapi mengalami derajat subyektivitas yang jauh lebih tinggi (Suhardjanto, 2008). Varian dari metode ini adalah jenis yang keempat. Dalam suatu jangkauan skor dengan bobot diferensial (berbeda), para stakeholder (pemangku kepentingan diperbolehkan memboboti setiap item indeks misalnya dari ' 0 ' sampai ' 3 '.

Penelitian ini menggunakan metode indek yang pertama, karena metode ini lebih obyektif seperti yang umumnya digunakan oleh para peneliti. Hal ini mengacu pendapat Suhardjanto (2008) metode yang pertama, sistem dikotomi dengan bobot sama, adalah yang paling umum digunakan pada penelitian pengungkapan sebelumnya.

\section{Corporate Governance (CG)}

Berle dan Means (1932) berpendapat bahwa konsepsi governance dibutuhkan sebagai konsekuensi terjadinya pemisahan antara kepemilikan dan kontrol atas suatu entitas perusahaan modern. Jensen dan Meckling (1986), menyatakan bahwa $C G$ merupakan sebuah sistem yang mempengaruhi strategi perusahaan serta keputusan yang diambil oleh manajer ketika ada pemisahan antara kepemilikan, pengendalian dan manajemen. Sukses atau tidaknya perusahaan ini ditentukan oleh keputusan atau strategi yang diambil oleh perusahaan.

Terdapat beberapa pengertian $C G$. Menurut Shleifer dan Vishny (1997), CG merupakan serangkaian mekanisme yang dapat melindungi pihak minoritas (ouside investor/minority shareholders) dari eksplorasi yang dilakukan oleh para manajer dan pemegang saham pengendali (insider) dengan penekanan pada mekanisme legal. Ho dan Wong (2001) berpendapat $C G$ merupakan cara yang efektif untuk menjelaskan hak dan tangungjawab masing-masing kelompok stakeholder dalam sebuah perusahaan dimana transparansi meru- pakan indikator utama standar $C G$ dalam sebuah perekonomian. Blair (1995) mendifinisikan $C G$ sebagai satu kesatuan menyeluruh mencakup aspek hukum, budaya dan kelengkapan institusional lainnya yang akan menentukan; hal apa saja yang dapat dilakukan oleh perusahaan, pihak mana yang akan melakukan pengendalian terhadap perusahaan dan bagaimana pengendalian tersebut dilakukan, serta bagaimana risiko dan manfaat dari berbagai aktivitas tersebut dialokasikan. Pengertian sederhana corporate governance diberikan oleh Cadbury (1999) bahwa $C G$ merupakan suatu sistem yang diharapkan berfungsi sebagai panduan bagaimana sebuah perusahaan diarahkan dan dikondisikan. Lannoo (1995) mendifinisikan $C G$ adalah suatu sistem yang menunjukkan sebagai suatu keseluruhan sistem tentang hak, proses dan kontrol yang digunakan secara internal dan eksternal oleh entitas bisnis dengan tujuan melindungi kepentingan stakeholders. Dari berbagai pengertian $C G$ diatas dapat disimpulkan, bahwa tujuan utama $C G$ adalah untuk menjaga kepentingan pemegang saham serta stakeholders lainnya supaya tidak dirugikan oleh proses pengelolaan perusahaan.

Menurut Monk dan Minow (1996) corporate governance menunjukkan hubungan berbagai partisipan dalam menentukan arah dan kinerja perusahaan. Corporate governance pada awalnya dipahami sebagai hubungan antara para pemegang saham, dewan komisaris, dan manajemen namun dalam perkembangannya, kelompok yang lain juga memiliki kepentingan dengan perusahaan sehingga tujuan dari corporate governance adalah untuk menjamin adanya keseimbangan dari seluruh kepentingan tersebut. Monk dan Minow (1996), menyatakan bahwa tujuan dari corporate governance adalah untuk menemukan cara untuk memaksimumkan peningkatan kekayaan setiap saat, artinya tidak membebankan biaya-biaya yang tidak semestinya terhadap pihak ketiga atau masyarakat secara keseluruhan. Aspek penting dari corporate governance mencakup: pengelolaan, kebijakan, dan supervisi. Li dan Qi (2008) menyatakan bahwa corporate governance dapat memberikan jaminan kualitas terhadap informasi akuntansi yang diungkapkan.

Forum for Corporate Governance in Indonesia (2001: 1) mendefinisikan corporate governance sebagai: 
"Seperangkat peraturan yang mengatur hubungan antara pemegang saham, pengurus (pengelola) perusahaan, pihak kreditur, pemerintah, karyawan serta para pemegang kepentingan intern dan ekstern lainnya yang berkaitan dengan hak-hak dan kewajiban mereka, atau dengan kata lain suatu sistem yang mengatur dan mengendalikan perusahaan."

Dari beberapa definisi tersebut dapat disimpulkan bahwa corporate governance meliputi seluruh struktur dan mekanisme yang digunakan untuk mengatur hubungan antara pemegang saham yang diwakili oleh dewan komisaris serta komite audit, manajemen, kreditur, karyawan, dan pihak lainnya yang terkait dengan perusahaan agar perusahaan dikelola dengan cara terbaik (efektif, efisien dan berkelanjutan) dan tidak merugikan pihak lain. Corporate governance pada akhirnya dapat meningkatkan kualitas informasi perusahaan termasuk dalam peningkatan luas pengungkapan serta dapat mendorong perusahaan untuk selalu berkembang secara berkelanjutan.

\section{Pengembangan Hipotesis}

\section{Perbandingan CSD Indonesia, Thayland dan Malaysia}

Dalam menerapkan konsep $C G$, Indonesia menganut sistem two-board system (Lukviarman, 2001; Sabeni, 2002), Thailand tidak jelas menganut two-board system maupun singleboard system (Kuarisikum dan Sherer 2004) sedangkan Malaysia menganut sistem singleboard system (Haniffa dan Cooke, 2005). Penelitian yang menguji pengaruh Corporate Governance $(C G)$ terhadap pengungkapan sosial sekaligus membandingkan praktik di beberapa negara misalnya dilakukan Aquilera, Williams, Conley dan Rupp (2006). Mereka melakukan penelitian dengan membandingkan pengaruh $C G$ terhadap praktik $C S D$ di United Kingdom (UK) dan United State (US), dan menyimpulkan bahwa perbedaan praktik pengungkapan sosial di Inggris dan Amerika disebabkan oleh perbedaan penerapan $C G$ di kedua negara. Berdasarkan uraian diatas maka dapat dirumuskan hipotesis sebagai berikut:
H1: Terdapat perbedaan praktik CSD di Indonesia, Thayland dan Malaysia.

\section{Ukuran dewan komisaris dan pengung- kapan sosial perusahaan}

Dewan komisaris adalah suatu bagian yang penting dalam mekanisme corporate governance dan merupakan pusat internal corporate governance (Lukviarman, 2007). Sesuai dengan pendapat Coller dan Gregory (1999), semakin besar jumlah anggota dewan komisaris, semakin mudah untuk mengendalikan Chief Executives Officer (CEO) dan semakin efektif dalam memonitor aktivitas manajemen. Dewan komisaris yang lebih besar menyajikan lingkungan yang lebih baik dan lebih banyak keahlian (Dalton, Daily, Johnson dan Ellstrand (1999).

Penelitian Nasution dan Setiawan (2007) di Indonesia menemukan bahwa ukuran dewan komisaris yang besar atau banyak akan lebih efektif jika dibandingkan ukuran dewan komisaris yang kecil atau sedikit. Temuan ini memperkuat hasil penelitian Sembiring (2005) di Indonesia yang menemukan ukuran dewan komisaris berpengaruh positif dan signifikan terhadap pengungkapan tanggung jawab sosial perusahaan. Semakin besar ukuran dewan komisaris maka akan semakin efektif mengawasi manajemen dalam mengungkapkan informasi, termasuk CSD. Oleh karena itu, semakin besar ukuran dewan komisaris diharapkan dapat meningkatkan tingkat pengungkapan sosial perusahaan. Berdasarkan uraian diatas, maka dapat dikembangkan hipotesis

$\mathrm{H} 2$ : Ukuran dewan komisaris berpengaruh positif terhadap tingkat pengungkapan sosial.

\section{Kompetensi komisaris utama dan peng- ungkapan sosial perusahaan}

Kompetensi komisaris utama dapat direpresentasikan dalam tiga cara yaitu latar belakang pendidikan, pengalaman dan jaringan atau net work (Reeb dan Zhao, 2009). Penelitian ini menggunakan kompetensi yang diukur dengan pengalaman komisaris utama. Semakin berpengalaman seorang komisaris utama cenderung memiliki kinerja yang lebih baik (Chemmanur dan Paeglis, 2004). Pengalaman komisaris utama dapat mempengaruhi keputusan dan masukan yang diberikan kepada dewan direksi, walaupun tidak ada keharusan 
bagi komisaris utama untuk memiliki pengalaman kerja di bidang sosial, lingkungan, dan budaya, namun lebih baik jika komisaris utama mempunyai pengalaman sosial, budaya, dan lingkungan. Pengalaman komisaris utama diperlukan karena tugas komisaris utama adalah sebagai primus inter pares yang mengkoordinasikan kegiatan dewan komisaris (KNKG, 2006).

Penelitian Reeb dan Zhao (2009); Chemmanur, Paeglis, dan Simonyan (2009); menyatakan bahwa pengalaman komisaris merupakan faktor yang menentukan dalam peningkatan nilai perusahaan dan kualitas pengungkapan perusahaan termasuk CSD. Komisaris utama yang memiliki pengalaman di bidang sosial, lingkungan, dan budaya akan lebih memiliki inisiatif untuk mengawasi manajemen dalam hal pengungkapan sosial perusahaan. Oleh karena itu, komisaris utama yang memiliki pengalaman kerja di bidang sosial, lingkungan, dan budaya diharapkan dapat meningkatkan pengungkapan sosial. Berdasarkan uraian tersebut, dapat dikembangkan hipotesis:

H3: Kompetensi komisaris utama berpengaruh positif terhadap tingkat pengungkapan sosial perusahaan.

\section{Proporsi komisaris independen dan pengungkapan sosial perusahaan}

Peran utama dewan komisaris adalah terkait dengan fungsi kontrol (Tubuan, 2005). Komisaris independen merupakan alat untuk mengawasi perilaku manajemen untuk meningkatkan pengungkapan informasi sukarela dalam laporan tahunan perusahaan (Rosenstein dan Wyatt, 1990). Komisaris yang berasal dari luar perusahaan dapat meningkatkan keefektifan dewan komisaris dalam melakukan fungsi utamanya, yaitu mengawasi pengelolaan perusahaan oleh manajemen (Fama dan Jansen, 1983).

Hasil penelitian di Hong Kong yang dilakukan oleh Ho dan Wong (2001) menemukan bukti bahwa proporsi komisaris independen berpengaruh positif terhadap tingkat keluasan pengungkapan termasuk pengungkapan sosial dan lingkungan. Di Indonesia, penelitian dilakukan oleh Andayani, Atmini, dan Mwangi (2008) menemukan bukti bahwa proporsi komisaris independen berpengaruh positif terhadap pengungkapan sosial dan ling- kungan. Proporsi komisaris independen yang lebih besar akan mendorong manajemen untuk mengungkapkan informasi sukarela, diantaranya pengungkapan sosial. Oleh karena itu, semakin besar proporsi komisaris independen diharapkan semakin meningkatkan keluasan pengungkapan sosial.

H4: Proporsi Komisaris Independen berpengaruh positif terhadap tingkat pengungkapan sosial perusahaan.

\section{Ukuran komite audit dan pengungkapan sosial perusahaan}

Van den Berge dan De Ridder (1999) mengemukakan tugas dari komite audit adalah: (1) mengawasi laporan keuangan dan pelaporan keuangan, (2) mengawasi sistem pelaporan dan sistem informasi manajemen termasuk CSD, (3) menguji sistem pengendalian keuangan (pengendalian intern dan ekstern) dan manajemen risiko, dan (4) mengawasi independensi external dan internal control, serta memilih auditor publik. Collier (1993) menyatakan bahwa komite audit mempunyai fungsi untuk meningkatkan kualitas laporan keuangan dan sebagai sistem pengendalian. Hasil penelitian Collier tersebut diperkuat oleh penelitian Ho dan Wong (2001) yang menunjukkan adanya hubungan positif antara ukuran komite audit dan luas pengungkapan.

Tugas komite audit yang cukup berat membutuhkan tidak hanya kemampuan tetapi juga jumlah yang cukup untuk bisa optimal dalam melaksanakan tugasnya. Semakin banyak jumlah komite audit maka akan semakin efektif dalam mengawasi kualitas pengungkapan laporan keuangan, termasuk CSD. Oleh karenanya semakin banyak anggota komite audit semakin meningkatkan kualitas pengungkapan sosial. Said, Zaenudin and Haron (2009) yang melakukan penelitian di bursa Malaysia menemukan bahwa size audit komite berpengaruh positif terhadap pengungkapan $C S D$. Berdasarkan uraian di atas, maka dapat dirumuskan hipotesis sebagai berikut:

H5: Ukuran komite audit berpengaruh positif terhadap tingkat pengungkapan sosial perusahaan.

Proporsi anggota komite audit independen
dan pengungkapan sosial perusahaan Forker (1992) menyatakan bahwa komite audit dapat meningkatkan pengendalian internal se- 
hingga dapat meningkatkan kualitas pengungkapan termasuk CSD. Menurut Ho dan Wong (2001) dan Yuen et al. (2009), komite audit secara signifikan dan positif berpengaruh terhadap tingkat pengungkapan sukarela.

Peran komite audit adalah mengawasi dan mengkaji proses perusahaan dalam menghasilkan data keuangan dan pengendalian internal, sehingga dapat mendorong manajemen menghasilkan pelaporan keuangan yang berkualitas tinggi. Keberadaan komite audit independen dengan proporsi yang lebih tinggi dari direktur dapat mengurangi biaya keagenan dan meningkatkan kontrol internal yang akan mengakibatkan kualitas pengungkapan yang lebih baik (Forker, 1992). Oleh karena itu, proporsi komite audit independen yang lebih besar diharapkan dapat meningkatkan pengungkapan sosial perusahaan. Berdasarkan uraian di atas, maka dapat dirumuskan hipotesis sebagai berikut:
H6: Proporsi anggota komite audit independen berpengaruh positif terhadap tingkat pengungkapan sosial perusahaan

\section{Kepemilikan manajerial dan pengungkapan sosial perusahaan}

Kepemilikan manajerial adalah kepemilikan perusahaan dari pihak manajemen yang terlibat aktif dan ikut dalam pengambilan keputusan perusahaan (Downes dan Goodman 1999). Antara manajemen dan pemegang saham biasanya melakukan kontrak kerja jangka panjang. Kontrak jangka panjang dapat dilakukan dengan memberikan insentif pada manajer apabila nilai perusahaan atau kemakmuran pemegang saham meningkat, salah satunya dengan cara memberi kepemilikan saham kepada manajer (Jensen dan Meckling, 1976; Fama, 1980). Dengan demikian, manajer akan termotivasi untuk meningkatkan nilai perusahaan atau meningkatkan kemakmuran pemegang saham karena hal tersebut juga akan meningkatkan kekayaan manajer.

\section{Gambar 1}

Skema Hubungan Antar Variabel Penelitian
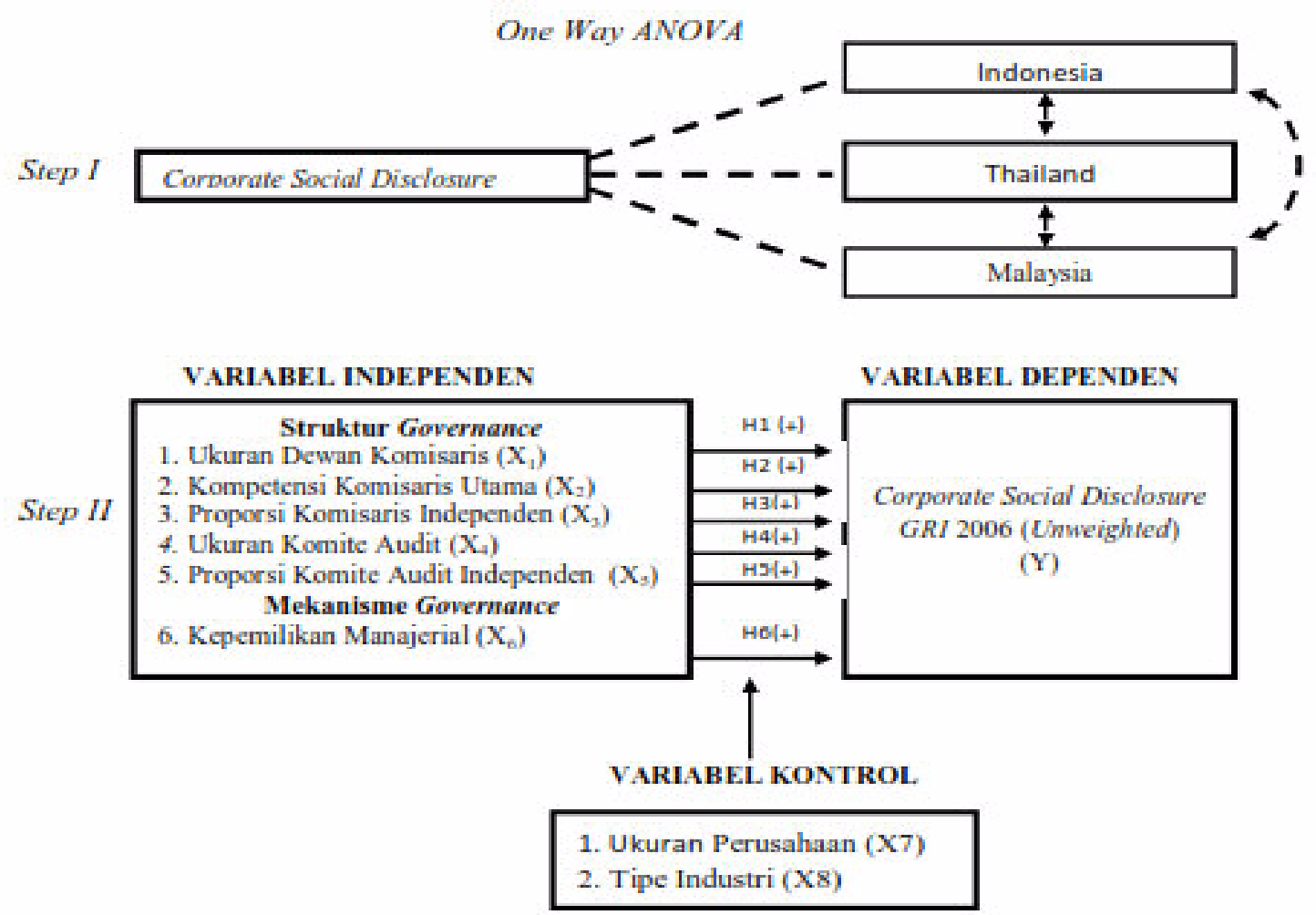
Manajer memiliki insentif yang lemah untuk bertindak sesuai kepentingan pemegang saham sehingga diperlukan kepemilikan manajerial untuk memotivasi manajer agar dapat memaksimalkan kinerjanya (Al-Fayoumi, Abuzayed dan Alexander, 2010), diantaranya pengungkapan sosial perusahaan. Semakin besar kepemilikan manajer di dalam perusahaan maka semakin kreatif dan produktif tindakan manajer dalam memaksimalkan nilai perusahaan, karena tindakannya mempengaruhi naik atau turunnya kepemilikan manajerialnya pada perusahaan. Manajer perusahaan akan mengungkapkan informasi sosial dalam rangka untuk meningkatkan image perusahaan, meskipun ia harus mengorbankan sumber daya untuk aktivitas tersebut Gray, et. al. (2001). Hal ini sesuai dengan penelitian Warfield, Wild and Wild (1995) dan Anggriani dan Retno (2006) di Indonesia. Semakin besar kepemilikan manajer diharapkan dapat meningkatkan pengungkapan sosial perusahaan. Berdasarkan uraian di atas, maka dapat dirumuskan hipotesis sebagai berikut:

H7: Kepemilikan manajerial berpengaruh positif terhadap tingkat pengungkapan sosial perusahaan

Penelitian ini dilaksanakan dalam dua tahap. Tahap pertama penelitian ini membandingkan pengaruh $C G$ terhadap praktik $C S D$ antara Indonesia, Thailand serta Malaysia. Tahap kedua adalah menguji apakah variabel indedependen berpengaruh terhadap variabel dependen dengan dua variabel kontrol.

\section{METODE PENELITIAN Populasi, Sampel, dan Teknik Pengambilan Sampel}

Populasi dalam penelitian ini adalah seluruh laporan tahunan (annual report) tahun 2009 dari perusahaan yang terdaftar di tiga bursa saham Indonesia, Malaysia dan Thailand. Total sebanyak 1792 dengan perincian 397 laporan tahunan perusahaan di Bursa Efek Indonesia (BEI), 823 laporan tahunan perusahaan di
Kuala Lumpur Stock Exchange (KLSE) dan 572 laporan tahunan perusahaan di Bursa Saham Thailand (TSE).

Pengambilan sample dilakukan secara acak dengan metode proporsional yaitu $10 \%$ dari populasi dengan memperhatikan jenis industri. Dengan metode ini peneliti bertujuan agar sampel dapat mewakili populasi. Akhirnya diperoleh sampel sebanyak 181 laporan tahunan (annual report) tahun 2009 yang terdiri 41 dari BEI, 83 dari KLSE dan 57 dari TSE dengan tiga kelompok jenis industry Manufaktur, Keuangan dan Jasa (Suhardjanto dan Afni 2009), seperti terlihat pada Table 2. Pemilihan tahun 2009 karena pada saat penelitian ini dilakukan laporan tahunan tersebut merupakan laporan tahunan yang terbit terakhir.

Teknik pengambilan sampel dilakukan secara random berbasis alokasi proporsional untuk meyakinkan sample merupakan representasi semua sektor industri (Haniffa dan Cooke, 2005). Sektor industri dalam penelitian ini dikelompokkan dalam tiga kategori yaitu jasa, keuangan dan manufaktur termasuk pertambangan.

\section{Data dan Metode Pengumpulan Data}

Data yang digunakan dalam penelitian ini berupa data sekunder yang diambil dari laporan tahunan (annual report) tahun 2009 di Indonesia, Malaysia dan Thailand. Data sekunder dari Indonesia dikumpulkan dari Indonesia Capital Market Directory (ICMD), IDX dan dari situs masing-masing perusahaan sample. Untuk sample perusahaan Malaysia dikumpulkan dari situs masing-masing perusahaan sample yang diunduh dari www.klse.com.my, sedangkan Thailand dari situs masing-masing perusahaan sample yang diunduh dari www.tse.com.id. Penelitian ini berbasis pada laporan tahunan, karena laporan tahunan mempunyai kredibilitas yang tinggi, selain itu, laporan tahunan digunakan sejumlah stakeholder sebagai sumber informasi (Deegan dan Rankin, 1997).

Tabel 2: Populasi dan Sampel menurut jenis industri

\begin{tabular}{lcccccc}
\hline Kelompok & \multicolumn{2}{c}{ Indonesia } & \multicolumn{2}{c}{ Malaysia } & \multicolumn{2}{c}{ Thailand } \\
\cline { 2 - 7 } Perusahaan & Populasi & Sampel & Populasi & Sampel & Populasi & Sampel \\
\hline Manufaktur & 185 & 19 & 568 & 57 & 405 & 40 \\
Keuangan & 127 & 13 & 38 & 4 & 69 & 7 \\
Jasa & 85 & 9 & 217 & 22 & 98 & 10 \\
\multicolumn{1}{c}{ Total } & 397 & 41 & 823 & 83 & 572 & 57 \\
\hline
\end{tabular}

Keterangan: Sampel 10\% dari populasi dengan pembulatan. 
Definisi Operasional dan Pengukuran Vair abel

\section{Variabel independen}

Variabel Independen direpresentasikan dengan ukuran dewan komisaris, komposisi dewan komisaris, proporsi komisaris independen, size komite audit dan proporsi komite audit independen.

\section{Ukuran dewan komisaris}

Ukuran dewan komisaris adalah banyaknya dewan komisaris yang ada didalam perusahaan yang berfungsi mengarahkan berbagai aktifitas perusahaan namun tidak bertanggung jawab untuk mengelolanya (Hunger dan Wheelen, 2000). Pengukuran yang digunakan dalam penelitian ini sesuai dengan penelitian Dalton, at al. (1999), yaitu jumlah keseluruhan anggota dewan komisaris yang dimiliki perusahaan baik yang berasal dari internal maupun eksternal perusahaan.

$$
\underset{\text { Komisaris }}{\text { Ukuran Dewan }}=\sum_{\text {Internal }}^{\text {Komisaris }}+\sum_{\text {Esternal }}^{\text {Komisaris }}
$$

\section{Kompetensi komisaris utama}

Penelitian ini menggunakan kompetensi yang diukur dengan lamanya pengalaman komisaris utama menjadi komisaris sebagai proksi dari kompetensi komisaris utama seperti yang dilakukan Chemmanur dan Paeglis (2004); Reeb dan Zhao (2009); yaitu lamanya waktu komisaris utama memiliki pengalaman sebagai komisaris dalam perusahaan yang sama maupun perusahaan lainnya. Pengukurannya dengan menjumlahkan angka tahun komisaris utama menjabat sebagai komisaris pada perusahaan, baik diluar maupun didalam perusahaan seperti yang digunakan Chemmanur dan Paeglis (2004); Reeb dan Zhao (2009).

\section{Proporsi komisaris independen}

Komisaris independen adalah anggota dewan komisaris yang tidak terafiliasi dengan manajemen, anggota komisaris lainnya dan pemegang saham pengendali, serta bebas dari hubungan bisnis atau hubungan lainnya yang dapat mempengaruhi kemampuannya untuk bertindak independen atau bertindak sematamata demi kepentingan peruahaan (Heriv dayatmo, 2000). Proporsi komisaris independen diukur dengan persentase anggota komisaris yang berasal dari luar perusahaan dari seluruh ukuran anggota komisaris perusahaan (Suhardjanto dan Afni, 2009). Indikator yang digunakan sesuai dengan penelitian Eng dan Mak (2003), Haniffa dan Cooke (2005), dan Suhardjanto dan Afni (2009), yaitu:

\section{$\begin{gathered}\text { Proporsi Komisaris } \\ \text { Independen }\end{gathered}=\frac{\sum \text { Komisaris Independen }}{\sum \text { Dewan Komisaris }}$ \\ size komite audit}

Size Komite Audit adalah jumlah komite audit yang bertugas menentukan eksternal auditor, mendiskusikan sifat dan scope audit, mendiskusikan cara audit, memberikan masukan, menjamin koordinasi bersama eksternal auditor, serta mereview laporan keuangan, mereview management letter dan mereview catatan pengendalian intern (Ho dan Wong, 2001). Pengukuran yang digunakan mengacu pada penelitian Ho dan Wong (2001) yaitu jumlah keseluruhan komite audit.

\section{Proporsi komite audit independen}

Komite Audit independen adalah anggota komite audit yang tidak terafiliasi dengan manajemen, anggota dewan komisaris lainnya dan pemegang saham pengendali, serta bebas dari hubungan bisnis atau hubungan lainnya yang dapat mempengaruhi kemampuannya untuk bertindak independen atau bertindak semata-mata demi kepentingan perusahaan (Forker, 1992). Proporsi komite audit independen diukur dengan menggunakan jumlah anggota dari luar perusahaan terhadap jumlah seluruh anggota komite audit, sesuai dengan penelitian Forker (1992), Nasution dan Setiawan (2007), Haniffa dan Cooke (2005); Suhardjanto dan Afni (2010) yaitu persentase anggota komite audit yang berasal dari luar perusahaan dari seluruh ukuran komite audit.

$$
\underset{\text { Audit }}{\text { Proporsi Komite }}=\frac{\sum \text { Komite Audit Independen }}{\sum \text { Total Komite Audit }}
$$

\section{Kepemilikan manajerial}

Kepemilikan manajerial adalah para pemegang saham yang berarti juga sebagai pemilik perusahaan dari pihak manajemen yang terlibat aktif dan ikut dalam pengambilan keputusan perusahaan (Downes dan Goodman 1998). Mengacu penelitian Warfield (1995), dan 
Anggriani dan Retno (2006) kepemilikan manajerial diukur dengan membagi jumlah saham yang dimiliki manajer dengan seluruh jumlah saham perusahaan.

$\underset{\text { Manajerial }}{\text { Kepemilikan }}=\frac{\sum \text { Saham yang dimiliki Manajemen }}{\sum \text { Total Saham }}$

\section{Variabel dependen}

Pengungkapan sosial di dalam penelitian ini menggunakan item yang terdapat pada indikator kinerja sosial yang terdapat di dalam GRI tahun 2006. Terdapat 22 aspek pengungkapan sosial Global Reporting Initiative (2006). Penelitian ini menggunakan pendekatan disclosure scoring atau yang disebut dichotomous, yaitu jika sebuah perusahaan mengungkapkan item yang terdapat dalam daftar, diberi nilai 1 , dan 0 jika tidak mengungkapkan (Suhardjanto dan Afni, 2009; Nurkhin, 2009).

Pengukuran tingkat pengungkapan menggunakan metode index yang tidak memperhatikan bobot masing-masing item pengungkapan (unweighted method), karena metode ini lebih obyektif dan banyak digunakan oleh para peneliti. Hal ini mengacu pendapat Suhardjanto, (2008) sistem dikotomi dengan bobot sama, adalah yang obyektif dan banyak digunakan pada penelitian pengungkapan sebelumnya. Adapun rumus untuk mengetahui skor atau nilai social disclosure adalah dengan menghitung persentase jumlah item social disclosure yang dilaporkan dibagi dengan total keseluruhan item, yang dituliskan dengan rumus sebagai berikut ini:

$$
\begin{aligned}
& \text { Corporate Social } \\
& \text { Disclosure }(C S D)
\end{aligned}=100 \% \times \frac{\sum X}{\sum N}
$$

Keterangan $\mathrm{X}=$ Item social disclosure yang diungkapkan di laporan tahunan, dan $\mathrm{N}=$ Total keseluruhan item.

\section{Variabel Kontrol}

Variabel kontrol yang digunakan dalam penelitian ini adalah ukuran perusahaan dan tipein dustri.

\section{Ukuran perusahaan (firm size)}

Ukuran perusahaan (firm size) dapat diproxykan dengan total assets, jumlah karyawan seperti yang digunakan dalam penelitian sebelumnya baik sebagai ukuran kombinasi atau ukuran yang berdiri sendiri. Mengacu pada penelitian sebelumnya yaitu Haniffa dan Cooke (2005), penelitian ini menggunakan $\log$ total aktiva sebagai dasar ukuran perusahaan karena total aktiva berisi keseluruhan aktiva yang dimiliki perusahaan baik yang lancar maupun tidak lancar, sehingga ini lebih menunjukkan ukuran perusahaan yang sebenarnya.

\section{Tipe industri}

Informasi yang diungkapkan oleh perusahaan biasanya sesuai dengan tipe industrinya (Haniffa dan Cooke, 2005). Beberapa penelitian di negara berbahasa Inggris, yang menjadikan tipe industry sebagai variabel dan menemukan adanya pengaruh signifikan ukuran perusahaan terhadap pengungkapan sosial antara lain dilakukan oleh: Belkaoui dan Karpik (1989), Hackston dan Milne (1996), Adams, Hills dan Roberts (1998), Gray, at. al. (2001). Penelitian di Indonesia antara lain Sembiring (2005) dan Suhardjanto dan Afni (2009), menemukan pengaruh positif signifikan ukuran perusahaan terhadap pengungkapan social. Dalam penelitian ini, perusahaan dibedakan menjadi tiga tipe industri yaitu: Service diberi kode 1, Finance diberi kode 2 dan Manufacture termasuk mining diberi kode 3 (Suhardjanto, 2008).

\section{Metode Analisis Data}

Penelitian ini menggunakan statistik deskriptif untuk menjelaskan karakteristik data dan uji hipotesis dengan menggunakan one way anova dan regresi berganda. Pengujian dilakukan dengan menggunakan software SPSS release 17. Sebagai persyaratan regresi berganda dilakukan uji asumsi klasik untuk memastikan bahwa data penelitian valid, tidak bias, konsisten dan penafsiran koefisien regresinya efisien (Gujarati, 2006), yang meliputi uji normalitas, uji multikolinieritas, uji autokorelasi dan uji heteroskedastisitas.

Pengujian hipotesis tahap pertama menggunakan uji One Way ANOVA dan tahap kedua menggunakan analisis regresi berganda. Uji One Way ANOVA digunakan untuk menguji perbedaan mean pada kelompok sample dimana fokusnya hanya pada jumlah kelompok yang lebih dari dua (Ghozali, 2006). Adapun rumus One Way ANOVA adalah sebagai berikut ini. 


$$
F=\frac{\text { Between Group Estimated Varian }}{\text { Within Group Estimated Variance }}
$$

Alat statistik ini digunakan untuk menguji perbedaan level pengungkapan sosial Indonesia, Malaysia dan Thailand. Kriteria pengujiannya adalah:

- Jika probabilitas > 0.05, maka H0 tidak dapat ditolak jadi variance sama berarti tidak ada beda praktik pengungkapan sosial diketiga negara.

- Jika probabilitas < 0.05, maka H0 ditolak jadi variance berbeda berarti ada perbedaan praktik pengungkapan sosial ditiga negara.

Untuk pengujian hipotesis pengaruh antara variabel dependen terhadap variabel independen digunakan rumus sebagai berikut:

$$
\begin{aligned}
C S D= & \beta_{0}+\beta_{1} \mathrm{UkDK}+\beta_{2} \mathrm{KompKU} \\
& +\beta_{3} \text { PropKI }+\beta_{4} \mathrm{UkKA}+ \\
& \beta_{5} \text { PPropKAI }+\beta_{6} \mathrm{KepM} \\
& +\beta_{7} \mathrm{UkP}+\beta_{8} \mathrm{TI}+\mathrm{e}
\end{aligned}
$$

\begin{tabular}{|c|c|}
\hline $\begin{array}{c}\text { Penjelasan } \\
\text { Variabel }\end{array}$ & Pengukuran \\
\hline Corporate Social & Memberi angka 1 pada item \\
\hline Disclosure (CSD) & $\begin{array}{l}C S D \text { yang diungkapkan } \\
\text { perusahaan dan angka } 0 \text { pada } \\
\text { item yang tidak diungkapkan } \\
\text { oleh perusahaan melalui } \\
\text { laporan tahunannya } \\
\text { kemudian dihitung } \\
\text { persentasenya. }\end{array}$ \\
\hline $\begin{array}{l}\text { UkDK (Ukuran } \\
\text { Dewan Komisaris) }\end{array}$ & $\begin{array}{l}\text { Menjumlah seluruh anggota } \\
\text { dewan komisaris. }\end{array}$ \\
\hline
\end{tabular}

\begin{tabular}{|c|c|}
\hline $\begin{array}{l}\text { KompDK } \\
\text { (Kompetensi }\end{array}$ & $\begin{array}{l}\text { Lamanya menjabat sebagai } \\
\text { dewan komisaris, semakin }\end{array}$ \\
\hline Dewan Komisaris) & $\begin{array}{l}\text { lama maka semakin } \\
\text { kompeten. }\end{array}$ \\
\hline PpropKI (Proporsi & Membandingkan jumlah \\
\hline Komisaris & komisaris independen \\
\hline Independen) & $\begin{array}{l}\text { terhadap keseluruhan dewan } \\
\text { komisaris } x 100 \% \text {. }\end{array}$ \\
\hline UkKA (Ukuran & Menjumlah seluruh anggota \\
\hline Komite Audit) & Komite Audit \\
\hline PropKAI (Proporsi & Membandingkan jumlah \\
\hline Komite Audit & anggota komite audit dari \\
\hline Independen) & $\begin{array}{l}\text { luar perusahaan terhadap } \\
\text { jumlah seluruh anggota } \\
\text { komite audit x } 100 \%\end{array}$ \\
\hline KepM & $\begin{array}{l}\text { Membagi saham yang } \\
\text { dimiliki manajer dibagi total }\end{array}$ \\
\hline $\begin{array}{l}\text { Uk P (Ukuran } \\
\text { Perusahaan) }\end{array}$ & Total Asset - $\log$. \\
\hline Tipe Industri (TI) & $\begin{array}{l}\text { 1. Perusahaan Jasa } \\
\text { 2. Keuangan } \\
\text { 3. Manufaktur termasuk } \\
\text { mining. }\end{array}$ \\
\hline
\end{tabular}

Keterangan :
Adapun kriteria hipotesis diterima atau ditolak ada tiga tingkatah adalah: $\mathrm{H}_{0}$ diterima jika $p$ value < dari 0,01 , < dari 0,5 serta $<$ dari 0,1 dan ditolak jika $p$-value >0,01 (Ghozali, 2005).

\section{ANALISIS DATA DAN PEMBAHASAN Deskriptif Data}

\section{Asia tenggara}

Pada Tabel 3 adalah hasil analisis statistik deskriptif di Asia Tenggara dengan menampilkan rerata (mean), standar deviasi, nilai minimum dan maksimum. Hasil dari analisis tersebut adalah sebagai berikut ini.

Tabel 3: Statistik Deskriptif Asia Tenggara

\begin{tabular}{llrrrr}
\hline No & \multicolumn{1}{c}{ Variabel } & Minimum & Maximum & \multicolumn{1}{c}{ Mean } & \multicolumn{1}{c}{ Std. Dev } \\
\hline 1. & CSD (\%) & 4.55 & 72.73 & 52.81 & 13.41 \\
2. & Ukuran Dewan Komisaris & 2.00 & 15.00 & 7.54 & 2.78 \\
3. & Kompetensi Komisaris Utama & 3.00 & 44.00 & 17.50 & 8.59 \\
4. & Proporsi Komisaris Independen (\%) & .00 & 100.00 & 43.37 & 14.21 \\
5. & Ukuran Komite Audit & 2.00 & 6.00 & 3.19 & .51 \\
6. & Proporsi Komite Audit Independen & .00 & 100.00 & 77.58 & 34.07 \\
& $(\%)$ & & & & \\
7. & Kepemilikan Manajemen (\%) & .00 & .98 & .14 & .19 \\
8. & Ukuran Perusahaan (Uk P) & 416584.00 & $5.7548 \mathrm{E} 8$ & $9.703023 \mathrm{E} 7$ & $1.0085007 \mathrm{E} 8$ \\
\hline N: 175 & & & &
\end{tabular}


Statistik diskriptif pada Tabel 3 menunjukkan bahwa tingkat corporate social disclosure di Asia Tenggara memiliki nilai rerata $52,81 \%$, rerata baru mengungkapkan 11,61 atau 12 poin kurang. Jumlah pengungkapan ini masih jauh dibawah 22 poin dimana aspek sosial yang idealnya diungkapkan menurut GRI 2006. Hal tersebut menunjukkan bahwa tingkat CSD pada annual report perusahaan di Asia Tenggara rendah. Dari total 175 sampel, 114 diatas rerata dan 61 dibawah rerata skor terendah yaitu $4,55 \%$ terjadi pada PT.DEFI dan skor tertinggi $68,18 \%$ dilakukan oleh PT. ASGR, PT. INDF, PT. KLBF, dan PT MDRN (di Indonesia), PT. AUTOAIR, PT. CCK, PT. CSCSTEEL, PT. D\&O, PT. DBHD, PT. FACBIN. PT NAIM, PT. NSB dan PT. AMWAY (di Malaysia) serta PT. PDI dan PT. WG (di Thailand).

Secara garis besar dapat dikatakan bahwa kesadaran manajemen di Asia Tenggara menunjukkan adanya peningkatan kemauan untuk melakukan pengungkapan sosial. Dari 175 sampel semua perusahaan telah melakukan pengungkapan begitu pula dari rata-rata pengungkapan sosial juga mengalami peningkatan disemua negara, meskipun tingkat kenaikan dan prosentasenya berbeda dan rendah.

Struktur dan mekanisme governance yang direprentasikan oleh Ukuran Dewan Komisaris (Jum DK), Kompetensi Komisaris Utama (Komp KU), Proporsi Komisaris Independen (Prop KI), Ukuran Komite Audit (Uk KA), Proporsi Komite Audit Independen (Prop KAI), Kepemilikan Manajemen (Kep M) dengan variabel kontrol Jumlah Aset (ASET) dan Tipe Industri (TI) nampaknya belum mampu mendorong meningkatkan kesadaran manajemen untuk melakukan CSD. Hal ini terlihat dari besarnya rata-rata $C S D$ yang rendah sementara mayoritas perusahaan telah memenuhi ketentuan pasar modal masingmasing negara.

Tabel 7: Hasil Analisis CSD dengan One Way ANOVA Indonesia, Thailand dan Malaysia Multiple Comparisons

Dependent Variable:CSD

\begin{tabular}{|c|c|c|c|c|c|}
\hline & (I) NEGARA & (J) NEGARA & $\begin{array}{c}\text { Mean } \\
\text { Difference (I-J) }\end{array}$ & Std. Error & p-value \\
\hline \multirow[t]{6}{*}{ Tukey HSD } & \multirow[t]{2}{*}{1} & 2 & $-18,3908^{*}$ & 2,17418 & $0,000 * * *)$ \\
\hline & & 3 & $-13,8239^{*}$ & 2,34484 & $0,000 * * *)$ \\
\hline & \multirow[t]{2}{*}{2} & 1 & $18,3908^{*}$ & 2,17418 & $\left.0,000^{* * *}\right)$ \\
\hline & & 3 & 4,5670 & 1,99366 & $\left.0,060^{*}\right)$ \\
\hline & \multirow[t]{2}{*}{3} & 1 & $13,8239^{*}$ & 2,34484 & $0,000 * * *)$ \\
\hline & & 2 & $-4,5670$ & 1,99366 & $\left.0,060^{*}\right)$ \\
\hline \multirow[t]{6}{*}{ Bonferroni } & \multirow[t]{2}{*}{1} & 2 & $-18,3908^{*}$ & 2,17418 & $0,000 * * *)$ \\
\hline & & 3 & $-13,8239^{*}$ & 2,34484 & $0,000 * * *)$ \\
\hline & \multirow[t]{2}{*}{2} & 1 & $18,3908^{*}$ & 2,17418 & $0,000 * * *)$ \\
\hline & & 3 & 4,5670 & 1,99366 & $\left.0,070^{*}\right)$ \\
\hline & \multirow[t]{2}{*}{3} & 1 & $13,8239^{*}$ & 2,34484 & $\left.0,000^{* * *}\right)$ \\
\hline & & 2 & $-4,5670$ & 1,99366 & $\left.0,070^{*}\right)$ \\
\hline
\end{tabular}

Catatan : $* * *)=$ signifikan pada $\alpha=0,01$

$* *)$ signifikan pada $\alpha=0,05$

$*)$ = signifikan pada $\alpha=0,1$

$1=$ Indonesia

$2=$ Malaysia

$3=$ Thailand

*. The mean difference is significant at the .05 level

Based on observed means.

The error term is Mean Square (Error) $=128.139$. 
Dari Tabel 7 di atas terlihat bahwa baik hasil Turkey HSD maupun Bonferoni menunjukkan terdapat perbedaan $C S D$ di Indonesia dibandingkan dengan di Malaysia dan di Thailand. Rerata perbedaan Indonesia terhadap Malaysia menurut Turkey HSD 18.3908, dan secara statistik signifikan dengan $p$-value $=$ 0,000 . Rerata perbedaan Indonesia terhadap Tahiland 13.8239 dan secara statistik signifikan dengan $p$-value $=0,000$. $C S D$ Malaysia terhadap Thailand baik menurut hasil Turkey HSD maupun Bonferoni menunjukkan hasil perbedaan mean 4.5670, artinya terdapat perbedaan namun perbedaannya kecil dan secara statistik tidak signifikan ( $p$-value $=0,060$ Turkey HSD dan $p$-value $=0,070$ Bonferoni) keduanya diatas 0,05 meskipun dibawah 0,1 .

Dari Tabel 8 di bawah memperkuat pernyataan bahwa CSD Indonesia dibanding Malaysia serta Thailand memiliki perbedaan yang signifikan. Hal ini terlihat Indonesia (1) dengan nilai mean 40,1332 berada di kolom subset 1, berbeda dengan Thayland (3) dan Malaysia (2) yang berada pada subset 2 dengan nilai mean berturut-turut 53,9570 dan 58,5240. Keberadaan Thailand (3) dan Malaysia (2) pada satu subset 2 juga menunjukkan bahwa keduanya memiliki perbedaan tetapi tidak terlalu besar dan tidak signifikan.

Ada indikasi bahwa perbedaan praktik CSD di Indonesia, Malaysia serta Thailand disebabkan oleh perbedaan praktik $C G$ di ketiga negara. Hal ini sejalan dengan temuan Aquilera, et al. (2006), dimana mereka melakukan penelitian dengan membandingkan pengaruh $C G$ terhadap praktik $C S D$ di United Kingdom (UK) dan United State (US) dan menyimpulan bahwa perbedaan praktik pengungkapan sosial di Inggris dan Amerika berasal dari perbedaan $C G$ dikedua Negara.

\section{Analisis Regresi Berganda}

Regresi berganda dalam penelitian ini digunakan untuk menjawab rumusan masalah yaitu menguji apakah $C G$ berpengaruh terhadap $C S D$. Pengujian regresi berganda ini dilakukan dengan metode backward. Metode backward adalah metode regresi dengan cara memasukkan keseluruhan variabel prediktor ke dalam analisis kemudian menguranginya satu demi satu prediktor guna menguji dan memastikan variabel yang benar-benar berpengaruh (Ghozali, 2006).

\section{Asia Tenggara}

Besarnya adjusted $R$ square pada Tabel 9 adalah 0,470 . Hal ini berarti bahwa kombinasi variabel independen yang terdiri dari Ukuran Dewan Komisaris (Uk DK), Kompetensi Komisaris Utama (Komp KU), Proporsi Komisaris Independen (Prop KI), Ukuran Komite Audit (Uk KA), Proporsi Komite Audit Independen (Prop KAI), Kepemilikan Manajemen (Kep M), Ukuran Perusahaan (Uk P) dan Tipe Industri (TI) dapat menjelaskan variabel dependen yaitu luas pengungkapan sosial perusahaan $(C S D)$ sebesar $47 \%$. Sisanya sebesar $53 \%$ pengungkapan informasi sosial dipengaruhi oleh faktor lain.

Tabel 8: Hasil tambahan Turkey test Nilai Mean Varibel Independen

$C S D$

\begin{tabular}{ccccc}
\hline NEGARA & & $\boldsymbol{N}$ & $\mathbf{1}$ & Subset \\
\hline Tukey HSD $^{\mathrm{a}, \mathrm{b}, \mathrm{c}, \mathrm{c}}$ & 1 & 41 & 40,1332 & $\mathbf{2}$ \\
& 3 & 54 & & 53,9570 \\
& 2 & 80 & 1,000 & 58,5240 \\
& Sig. & & & 0,093 \\
\hline
\end{tabular}

Means for groups in homogeneous subsets are displayed.

Based on observed means.

The error term is Mean Square(Error) $=128,139$.

a. Uses Harmonic Mean Sample Size $=54,143$.

b. The group sizes are unequal. The harmonic mean of the group sizes is used. Type I error levels are not guaranteed.

c. Alpha $=.05$.

Keterangan: 1 Indonesia

2 Malaysia

3 Thailand 
Tabel 9: Hasil Regresi Linier Berganda (Asia Tenggara)

\begin{tabular}{lccc}
\hline & $\mathrm{B}$ & $\mathrm{t}$ & $\mathrm{p}$-value \\
\hline (Constant) & $-7,901$ & $-0,738$ & 0,462 \\
Ukuran Dewan Komisaris & 0,812 & 2,088 & $\left.0,038^{* *}\right)$ \\
Kompetensi Komisaris Utama & 0,025 & 0,268 & 0,789 \\
Proporsi Komisaris Independen & 0,131 & 2,215 & $\left.0,028^{* *}\right)$ \\
Ukuran Komite Audit & 3,472 & 2,295 & $\left.0,023^{* *}\right)$ \\
Proporsi Komite Audit Independen & 0,151 & 4,662 & $0,000^{* * *)}$ \\
Kepemilikan Manajemen & $-3,901$ &,- 955 & 0,341 \\
Tipe Industri & 6,776 & 5,863 & $\left.0,000^{* * *}\right)$ \\
Ukuran Perusahaan & 7,079 & 6,024 & $0,000^{* * *)}$ \\
R Square & 0,494 & & \\
Adjusted R Square & 0,479 & & \\
F & 33,001 & & \\
Sig & 0,000 & & \\
\hline
\end{tabular}

Catatan : ***) $=$ signifikan pada $\alpha=0,01$

$* *)$ = signifikan pada $\alpha \dot{\alpha}=0,05$

*) = signifikan pada $\alpha=0,1$

Nilai $F$ Hitung 33,001 dengan tingkat signifikansi 0,000 (p value $<5 \%$ ). Karena nilai F lebih besar dari 4,000 dan nilai Sig jauh lebih kecil dari 0,05, maka dapat disimpulkan bahwa kombinasi variabel independen dengan varibel kontrol secara bersama sama mempengaruhi pengungkapan sosial perusahaan (CSD) (Ghozali, 2006). Hal ini bisa dikatakan juga bahwa model regresi berganda baik (goodness of fit).

Berdasarkan pengujian hipotesis yang dilakukan, hasilnya menunjukkan bahwa Ukuran Dewan Komisaris (Uk DK), Proporsi Komisaris Independen (Prop KI), Ukuran Komite Audit (Uk KA), Proporsi Komite Audit Independen (Prop KAI) (varibel independen) dan Tipe Industri (variabel kontrol) berpengaruh positif signifikan ( $p$-value $<5 \%)$ terhadap $C S D$, sedangkan Kepemilikan Manajemen (Kep M) dan Kompetensi Komisaris Utama (Komp KU) (variabel independen) serta Ukuran Perusahaan (Uk P) (variabel kontrol) tidak berpengaruh terhadap CSD.

Pengujian pengaruh Ukuran Dewan

Komisaris (Uk DK) terhadap tingkat CSD dalam laporan keuangan perusahaan pada Tabel 9 menunjukkan nilai t hitung 2.088 sedang $p$ value menunjukkan angka 0,038 , lebih kecil dari 0,05 . Hal ini dapat disimpulkan bahwa Ukuran Dewan Komisaris (Uk DK) di Asia Tenggara berpengaruh signifikan terhadap luas pengungkapan sosial perusahaan $(C S D)$ berarti pula hipotesis 2 diterima. Atau dapat pula dikatakan bahwa semakin besar Dewan Komisaris semakin luas pula $C S D$. Keadaan ini disebabkan karena semakin banyak Dewan Komisaris maka memiliki kekuatan yang lebih besar untuk menyarankan pada manajemen untuk melaksanakan $C S D$ dengan baik dibanding dengan jumlah Dewan Komisaris yang sedikit. Temuan ini sejalan dengan hasil penelitan Nasution dan Setiawan (2007) yang menemukan bahwa ukuran dewan komisaris yang besar akan lebih efektif jika dibandingkan ukuran dewan komisaris yang sedikit.

Hasil regresi Kompetensi Komisaris Utama menunjukkan nilai $\mathrm{t}$ hitung 0,268 sedang $p$-value menunjukkan angka 0,789 jauh diatas 0,05. Hal ini berarti Kompetensi Komisaris Utama (Kom KU) tidak berpengaruh signifikan terhadap luas pengungkapan sosial perusahaan $(C S D)$ berarti pula hipotesis 2 ditolak. Hal ini disebabkan kurangnya perhatian Komisaris Utama dalam masalah CSD meskipun mayoritas Komisaris Utama telah memiliki pengalaman yang cukup, karena jika dilihat rereta Komisaris Utama telah memiliki pengalaman 17,50 tahun. Hasil penelitian ini tidak sejalan dengan penelitian Reeb dan Zhao (2009); Chemmanur, Paeglis, dan Simonyan (2009); yang menemukan kompetensi komisaris utama merupakan faktor yang me- 
nentukan dalam peningkatan nilai perusahaan dan kualitas pengungkapan perusahaan. Perbedaan ini disebabkan oleh lokasi serta jumlah sampel penelitian

Proporsi Komisaris Independen pada tabel 9 menunjukkan nilai $\mathrm{t}$ hitung 2,215 sedang p-value menunjukkan angka 0,038 dibawah atau lebih kecil dari 0,05. Hal ini berarti Proporsi Komisaris Independen (Prop KI) di Asia Tenggara berpengaruh signifikan terhadap luas pengungkapan sosial perusahaan $(C S D)$ berarti pula hipotesis 3 diterima. Kondisi ini terjadi karena Komisaris Independen pada umumnya telah dan mampu menjalankan fungsinya dengan baik dan rerata proporsi komisaris independen di Asia Tenggara juga baik yaitu 43,37. Hasil penelitian ini sejalan dengan Andayani et al. (2008) di Indonesia yang menemukan bukti bahwa proporsi komisaris independen berpengaruh positif terhadap pengungkapan sosial.

Ukuran komite audit menunjukkan nilai $t$ hitung 2,295 sedang $p$-value menunjukkan angka 0,023 lebih kecil dari 0,05. Hal ini berarti Ukuran Komite Audit (Uk KA) berpengaruh positif signifikan terhadap luas pengungkapan sosial perusahaan $(C S D)$ berarti pula hipotesis 4 diterima. Kondisi ini merupakan hal yang semestinya terjadi karena semakin besar Ukuran Komite Audit, maka semakin kuat mereka menyarankan pada manajemen untuk memprkatikkan CSD yang lebih baik. Temuan ini sejalan dengan hasil penelitian Said. et al. (2009) di Malaysia yang menemukan bahwa ukuran audit komite berpengaruh positif terhadap pengungkapan $C S D$.

Hasil regresi Prop KAI menunjukkan nilai $t$ hitung 4,662 sedang $p$-value menunjukkan angka 0,000 lebih kecil dari 0,05. Hal ini berarti Proporsi Komite Audit Independen (Prop KAI) berpengaruh positif signifikan terhadap luas pengungkapan sosial perusahaan $(C S D)$ berarti pula hipotesis 5 diterima. Hal ini karena semakin besar Proporsi Komite Audit Independen maka semakin kuat juga mereka menyarankan pada manajemen untuk mempraktikan $C S D$ lebih baik. Temuan ini sejalan dengan hasil penelitian Said. et al. (2009) di Malaysia dan diperkuat temuan Ho dan Wong (2000) di Hongkong yang menemukan adanya hubungan positif antara proporsi komite audit terhadap luas pengungkapan.
Kepemilikan manajemen pada Tabel 9 menunjukkan nilai $\mathrm{t}$ hitung 0,955 sedang $p$ value menunjukkan angka 0,341 diatas 0,05. Hal ini berarti Kepemilikan Manajemen (Kep M) tidak berpengaruh positif signifikan terhadap luas pengungkapan sosial perusahaan $(C S D)$ berarti pula hipotesis 6 ditolak. Penyebabnya karena Kepemilikan Manajemen di Asia Tenggara masih teramat kecil yaitu rerata baru $0,14 \%$ maka kepemilikan manajemen tidak memiliki kemampuan memberikan dorongan atau memotivasi manajemen yang juga memiliki saham perusahaan untuk mempraktikkan $C S D$ yang lebih baik. Hasil penelitian ini tidak sejalan Anggraini (2006) di Indonesia yang menemukan adanya pengaruh antara kepemilikan manajerial terhadap pengungkapan sosial. Hal ini kemungkinan karena kecilnya prosentase (rerata 0,14\%) kepemilikan manajemen sehingga tidak mampu memotivasi manajemen untuk mempengaruhi CSD.

\section{KESIMPULAN DAN IMPLIKASI}

Berdasarkan hasil analisis deskriptif, dapat diketahui bahwa besarnya $C S D$ di ketiga negara sample berturut-turut adalah Malaysia dengan rerata (mean) $58.52 \%$, Thailand dengan rerata (mean) 54,12\% dan Indonesia dengan rerata (mean) 40,14\%. Ada indikasi manajemen di Malaysia dan Thailand telah memiliki kesadaran yang lebih tinggi dalam mengungkapkan aktifitas sosialnya dibanding Indonesia. Secara keseluruhan praktik $C S D$ diketiga negara rendah, hal ini dikarenakan adanya pandangan yang mengangap tidak penting mempraktikan CSD bahkan praktik CSD dianggap hanya menghamburkan biaya bagi perusahaan.

Hasil analisis one way ANOVA menunjukkan bahwa pengaruh praktik $C G$ terhadap CSD pada negara-negara di Asia Tenggara memang memiliki perbedaan. Hal ini dibuktikan baik melalui metode Turkey HSD maupun Bonferoni Kedua metode menunjuk kan hasil yang sama dimana perbedaan $\operatorname{CSD}$ di Indonesia terhadap CSD di Malaysia dan Thailand signifikan secara statistik dimana nilai sig 0,000 dibawah 0,05, sementara perbedaan $C S D$ di Malaysia dan Thailand tidak signifikan secara statistik dimana berdasarkan metode Turkey HSD nilai signifikansi 0,84 dan menurut metode Bonferoni nilai signifikansi 0.104 keduanya diatas 0,05 . 
Hasil uji regresi corporate governance yang diproksikan dengan Ukuran Dewan Komisaris (JumDK), Kompetensi Dewan Komisaris (Komp DK), Proporsi Komisaris Independen (Prop KI), Ukuran Komite Audit (Size KA), Proporsi Komite Audit Independen (Prop KAI), Kepemilikan Manajemen (Kep M), dengan varibel kontrol Ukuran Perusahaan (Uk P) dan Tipe Industri (TI) terhadap CSD ditemukan bahwa: di Asia Tenggara secara keseluruhan memiliki peran yang cukup besar dimana empat varibel $C G$ berpengaruh positif signifikan terhadap $C S D$. Artinya $C G$ cukup berperan dan diperlukan dalam rangka meningkatkan manajemen untuk melakukan dan menginformasikan aktifitas sosialnya.

Hasil analisis masing-masing negara, menunjukkan pengaruh $C G$ terhadap $C S D$ adalah: di Indonesia 4 variabel $C G$ yang berpengaruh positif signifikan, kemudian Tahiland dengan 3 variabel berpengaruh positif signifikan. Adapun di Malaysia hanya satu varibel $C G$ yang berpengaruh negatif signifikan moderat. Hal ini disebabkan praktik penerapan $C G$ diketiga negara tersebut memang berbeda. Di Indonesia menganut two tire board dimana posisi Direksi dan Komisaris terpisah dalam sutruktur organisasi sehingga komisaris memiliki peran yang lebih kuat dalam kontrol terhadap manajemen. Sedangkan praktik penerapan $C G$ di Thailand tidak begitu jelas apakah menggunakan two tire board maupun one tire board dan hanya 3 variabel yang berpengaruh. Malaysia menganut sistem one tire board dimana komisaris berada dalam satu board dengan manajemen dan disebut board, mengakibatkan kontrol komisaris terhadap manajemen tidak sekuat sistem two tire board sehingga Komisaris tidak berpengaruh terhadap CSD sebagai bagian dari informasi yang disampaikan oleh manajemen, karena level mereka didalam struktur organisasi sederajad.

Temuan yang unik dalam penelitian ini adalah meskipun $C G$ di Malaysia hanya satu yang variabel $C G$ yang berpengaruh positif signifikan moderat terhadap CSD, CSD di Malaysia memiliki tingkat tertinggi $58.52 \%$ banding ketiga negara sampel, diikuti Thailand yang sedikit dibawahnya yaitu $54,12 \%$ dan Indonesia yang jauh dibawahnya yaitu $40,14 \%$. Artinya, mayoritas manajemen di Malaysia memiliki kesadaran yang lebih tinggi dalam melakukan serta pengungkapan aktifitas sosial perusahaan tanpa diminta atau disarankan oleh komisaris maupun komite audit sebagai bagian dari struktur $C G$. Pengungkapkan aktifitas sosialnya juga tidak berdasarkan besarnya kepemilikan manajemen di perusahaan tersebut serta tidak terpengaruh oleh besar kecilnya asset yang dimiliki maupun karakter industrinya.

\section{DAFTAR PUSTAKA}

Adams,C; Hill, W.Y. and Robert, C.B., 1995, Environmental, employee and ethical reporting in Europe. AACA. London.

At Fayoumi, N., Abuzayed, B. and Alexander, D. 2010. Ownership Structure and Earnings Management in Emerging Markets: The Case of Jordan. International Research Journal of Finance and Economics. (38): 28-47.

Andayani, W., Atmini, S., dan Mwangi, J.K., 2008. Corporate Social Responsibility, Good Governance and the Intelectual Property: An Exsternal Strategy of the Mangement to Increase the Company's Value. National Conference on Management Research. Makasar.

Anderson, J.C., and Frankle, A. W., 1980. Voluntary social reporting; An iso-beta portofolio analysis. The Accunting Review. 55 (3): 467-479.

Anggraini, F., dan Retno, R., 2006. Pengungkapan informasi sosial dan faktor-faktor yang mempengaruhi pengungkapan informasi sosial dalam laporan keuangan tahunan (studi empiris pada perusahaan-perusahaan yang terdaftar di Bursa Efek Jakarta), Makalah disampaikan pada Simposium Nasional Akuntansi IX, Padang, 23-26 Agustus 2006.

Aquilera, R.V., Williams, C.A., Conley, J.M. and Rupp, D.,E., 2006. Corporate Governance and Social Responsibility: a comparative analysis of the UK and the US. Corpoate Governance and Social Responsibility. 14 (3):147-158.

Balou, B.; D. L. Heitger, and C. E. Landes, 2006. The future of corporate 
sustainability reporting. Journal of Accountancy. 202 (6): 65-74.

Belkaoui, A., and Karpik, P. G., 1989. Determinants of The Corporate Decision To Disclose Social Information. Accounting, Auditing and Accountability Journal (2): 36-51.

Berle, A. A., and Means, G. C., 1934. The Modern Corporation and Privat Property, Originally Publised in 1932. New editiond-second printing 1997, Transaction Publisher, New Jersey.

Blair, M. M., 1995. Ownership and Control: Rethinking Corporate Governance for the Twnty-first Country. The Brooking Institutional, New York.

Cadbury Committee, 1992. Report of The Committe on The Financial Aspects of Corporate Governance. London: Gee.

Chemmanur, T.J., and Paeglis, I., 2004. Management Quality, Certification, and Initial Public Offering. Jurnal of Financial Economics. 76 (1): 331-368.

Chemmanur, T.J.; Paeglis, I. and Simonyan, K., 2009. Management Quality, Financial and Investment Policies, and Asymmetric Information. Journal of Financial and Quantitatives Analysis. 44 (5): 1045-1079.

Collier, P., 1993. Factors affecting the formation of audit committees in major UK listed companies. Accounting and Business Research. 23: 421-430.

Coy, D.; Tower, G. and Dixon, K., 2004. Quantifiying the quality of tertiary education annual reports. Accounting and Finance. 33 (2): 121-130.

Dalton, D. R.; C. M. Daily; J. L. Johnson and A. E. Ellstrand, 1999. Number of Directors and Financial Performance: A Meta-Analysis. Academy of Management Journal. 42: 674-686.

Deegan, C., 2002. "The Legitimising Effect Of Social And Environmental DisclosuresA Theoretical Foundation", Accounting, Auditing and Accountability Journal. 15 (3): 282-312.
Deegan, C. and Rankin, M., 1997. The materiality of environmental information to users of annual report. Accounting, Auditing and Accountability Journal. 10 (4): 562-583.

Downes, J. and Goodman, J.E., 1998. Dictionary of Finance and Investment Term, Barrons Educational Series.

Eng, L.L., and Mak, Y.T., 2003. Corporate governance and voluntary disclosure, Journal of Accounting and Public Policy. 22: 325-345.

Fama, E.F., 1980. Agency Problems and Theory of The Firm, Journal of Political Economy. 88: 288-307.

Fama, E.F., and M.C. Jensen, 1983. The Separation of Ownership and Control. The Journal of Low and Economics. 26: $301-325$.

Forum for Corporate Governance in Indonesia (FCGI). 2001. Tata Kelola Perusahaan (Corporate Governance). Jilid II: "Peranan Dewan Komisaris dan Komite Audit dalam Melaksanakan Corporate Governance".

Ghozali, I., 2006. Aplikasi Analisis Multivariate dengan Program SPSS. Badan Penerbit Universitas Diponegoro.

Gray, R.; D. Owen and K. Maunders, 1987. Corporate Social Reporting: Accounting and Accountability, Prentice-Hall, London.

Gray, R.; Javad, M.; Power, D. M., and Sinclair, C. D., 2001. Social and Environmental Disclosure and Corporate Characteristics: A Research Note Extension. Journal of Business and Accounting 28: 327-356.

GRI Report List, 2010. www.sustainabilityreports.com.

Gujarati, D. N., 2006. Basic econometrics (4th edition). Singapore: McGraHill.

Forker, J.J., 1992. Corporate Governance and Disclosure Quality. Accounting and Business Research. Spring: pp. 111124. 
Hackston, D., and Milne, M.J., 1996. Some Determinant Of Social And Environmental Disclosures In New Zealand Companies. Accounting, Auditing \& Accountability Journal. 9: 77-108.

Haniffa, R. M., and Cooke, T. E., 2005. The Impact of Culture and Governance on Corporate Social Reporting. Journal of Accounting and Public Policy. 24: 391-430.

Herwidayatmo, 2000. Implementasi good corporate governance untuk perusahaan publik Indonesia, Majalah Usahawan. 10 (29): 25-32.

Ho, S.S. and Wong, K.S., 2001. A study of the relationship between corporate governance structures and the extent of voluntary disclosure. The Journal of International Accounting, Auditing and Taxation 10: 139-156.

Hunger, D. G. and Whellen, T.L., 2000. Trategic Management. Prentice Hall.

Jensen, M., and Meckling, W., 1976. Theory of the firm: managerial behavior, agency costs and ownership structure. Journal of Financial Economics. 3: 82-136.

Komite Nasional Kebijakan Governance. 2006. Pedoman Umum Good Corporate Governance.

http://www.cicfcgi.org/news/files/Pedo man_GCG_060906.pdf.

Kuasirikun, N. And Sherer, M. 2004. Corporate social accounting disclosure in Thailand. Accounting, Auditing \& Accountability Journal. 17 (4): 629 660.

Lannoo, K. 1995. Corporate Governance in Europe. Centre for European Policy Studies. CEPS Workiing Party Report.

Li, Hongxia and Ainian Qi., 2008. Impact of Corporate Governance on Voluntary Disclosure in Chinese Listed Company. Corporate Ownership and Control, 5.

Lukviarman, N., 2001. Key characteristics of corporate governance: The case of Indonesia. Working Paper Series 01.01, Graduate School of Business, Curtin University of Technologi, Perth.
Lukviarman, N., 2007. Board Governace Menuju Penguatan Corporate Governance di Indonesia. Pidato Pengukuhan Sebagai Guru Besar Tetap Dalam Bidang Corporate Governance, Pada Fakultas Ekonomi Universitas Andalas, Padang 7 Juni 2007.

Monks, R. A and Minow, N., 1996. Corporate Governance. Blackwell Business.

Murwaningsari, E., 2008. Hubungan corporate governance, corporate social responsibility dan financial performace dalam satu continuum. The $2^{\text {nd }}$ Accounting Coference, $1^{\text {st }}$ Doctoral Colloquium, and Accounting Workshop, Depok, 4-5 November 2008.

Nasution, M. dan Setiawan, D., 2007. Pengaruh corporate governance terhadap manajemen laba di industri perbankan. Simposium Nasional Akuntansi X. Makassar. Ikatan Akuntan Indonesia.

Nurkhin, A., 2009. Corporate Governance dan Profitabilitas; Pengaruhnya terhadap Pengungkapan tangung Jawab Sosial Perusahaan, Studi Empiris di BEI, www.eprints.undip.ac.id, diakses tanggal 28 Mei 2010.

Parker, L., 1986, Polemical Themes in Social Accounting: A Scenario for Standard Setting, In Nelmark, M., Merino, B. and Tinker T., (Eds) Advaces in Public Interest Accounting, Vol 1, Greenwich: JAI Pres Inc, pp. 67-93.

Reeb, D.M. and Zhao. W., 2009. Director Capital and Corporate Disclosure Quality.

http://69.175.2.130/ finman/Reno/Pape rs/legalexpertise.pdf. Diakses tanggal 4 Maret 2011.

Rosenstein, S. and Wyatt, J.G., 1990. Outside directors, board independence, and shareholder wealth. Journal of Financial Economic. 26: 175-192.

Sabeni, A., 2002. An Empirical Analysis of The Relaitionship Between The Board of Director's Composition and The Level of Voluntary Disclosure. Makalah dipresentasikan pada Simposium Nasional Akuntansi Semarang. 
Said, R.; Zaenudin, Y., and Haron., 2009. The relationship between corporate social responsibility disclosure and corporate governance characteristics in Malaysian public listed companies. Social Responsibility Journal 5: 212226.

Sembiring, E.R., 2005. Karakteristik perusahaan dan pengungkapan tangungjawab social: Studi empiris pada perusahaan yang tercatat di Bursa Efek Jakarta, Makalah disampaikan pada Simposium Nasional Akuntansi VIII, Surakarta, 16-17.

Shleifer, A. dan Robert, W. V., 1997. A Survey of Corporate Governance. 52 (2).

Suhardjanto, D., 2008, Environmental reporting practices: an empirical study in Indonesia. Disertation Curtin University of Technology.

Suhardjanto, D., dan Afni, A. N.. 2009. Praktik Corporate Social Disclosure di Indonesia. Jurnal Akuntansi/Tahun XIII (3): 265-279.

Suhardjanto, D. dan Dewi, A. 2011. Pengungkapan Risiko Finansial dan Tata Kelola Perusahaan: Studi Empiris Perbankan Indonesia. Jurnal Keuangan dan Perbankan 15 (1): 105-118.
Suhardjanto, D., Tower, G. and Brown, A., 2008. Indonesian Stakeholders' Perception on Environmental Information. Jurnal of The Asia-Pacific Centre for Environmental Accountability 14 (4): 2-11.

Tubuan, F. B. G., 2005. The Two Tier Board and Corporate Governance, paper yang dipresentasikan pada "One-day Seminar on Capital Market and Corporate Governance Issues in Indonesia" Bali, 7 September 2005.

Utama, S., 2003. Corporate Governance, Disclosure and Its Evidence In Indonesia. Usahawan no. 04 th XXXII. Hlm. 28-32.

Van den Berghe, L., and L. De Ridder, 1999. International Standardisation of Good Corporate Governance: Best Practice for The Board of Directors. Kluwer Academic Publishers.

Warfield, T.D.; Wild, J.J., and Wild, K.L., 1995. Managerial ownership, accounting choices, and informativeness of earnings. Journal of Accounting and Economics. 20: 61-91.

Yuen, D.C.Y., Liu, M., Zhang, X., and Lu, C., 2009. A Case Study of Voluntary Disclosure by Chinese Enterprises. Asian Journal of Finance \& Accounting. 1: 118-139. 